U.S. Department of the Interior U.S. Geological Survey

\section{Directions of Ground-Water Flow \\ in the Lost River Watershed \\ Near Orleans, Indiana}

\section{The Mysterious River}

The Lost River is one of the most fascinating hydrologic systems in Indiana. Just as the imaginations of the Indians and early settlers were captured by this scenic and mysterious river, naturalists, scientists, and adventurers today are attracted to the same waters.

Above the Orangeville Rise, the Lost River drains 163 square miles of southern Indiana's hilly forests and farmlands. Appropriately named, the Lost River Basin is characterized by sinkholes and streambed swallow holes into which most of the headwaters "disappear" near the central part of the watershed. The water that leaves the surface by flowing into these natural openings travels underground through fractures and joints in the limestone. Most of the water returns to the surface at the Orangeville Rise; water also resurfaces at Twin Caves, Hamer Cave, Rise of Lost River, and other springs.

The people who live in and around the Orleans area enjoy the beauty of the Lost River landscape; however, they also must face the possibility of local flooding of the Lost River and its tributaries. An improved understanding of that hydrologic system is needed to make effective water-management choices.

\section{Lost River Investigation}

The U.S. Geological Survey (USGS) in cooperation with the U.S. Army Corps of Engineers, conducted a scientific investigation on the Lost River in 1993 and 1994. The purpose of the study was to improve an understanding of the ground-water-drainage boundaries of the Lost River Watershed and the hydrogeology near the town of Orleans, a community subject to frequent flooding.

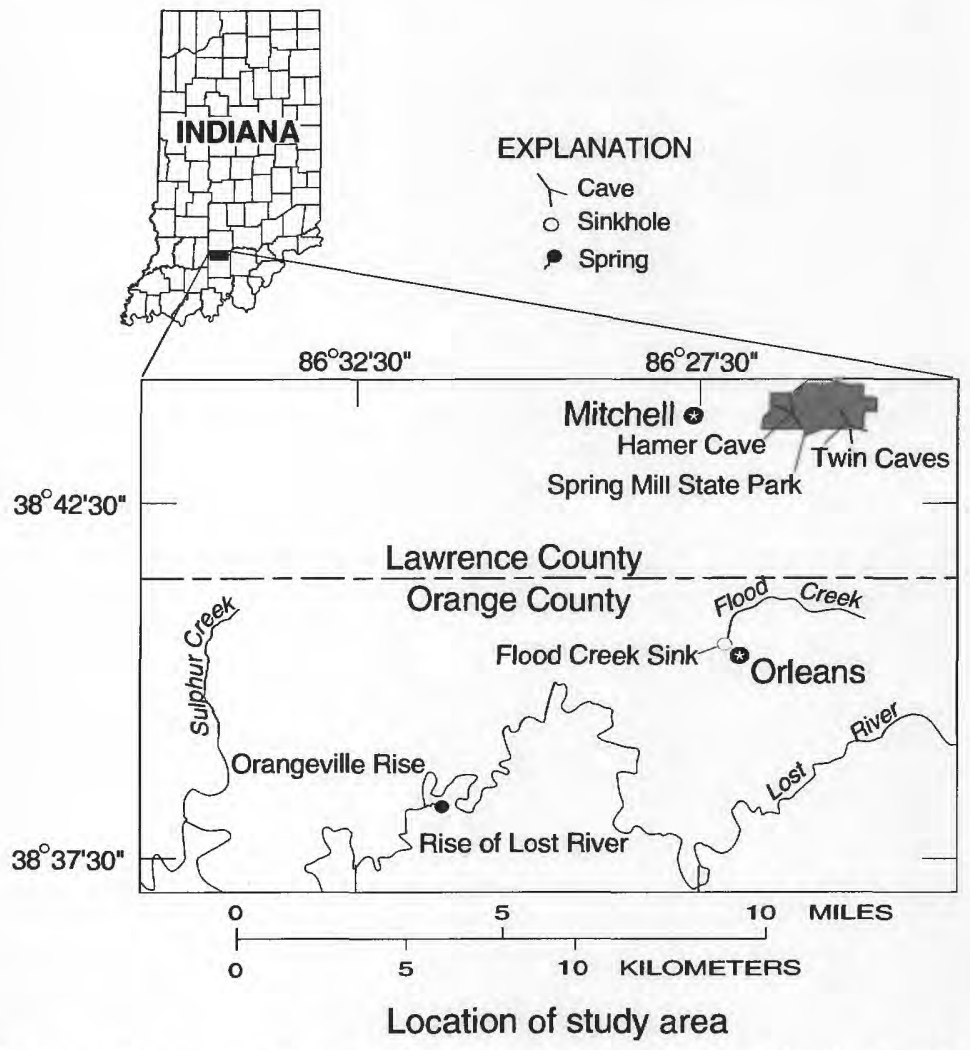

Drainage boundaries were delineated and the direction of underground flows was determined in the Lost River Watershed by an analysis of water-level data and by observation of the emergence of fluorescent dyes that were injected at sinkholes and swallow holes. In addition, factors that contribute to flooding at Orleans were investigated. This information will be useful for future flood-control designs.

This fact sheet presents a brief description of this 1993-94 study and a summary of the results. A more detailed presentation can be found in USGS Water-Resources Investigations Report 94-4195, "Directions of ground-water flow and locations of ground-water divides in the Lost River Watershed near Orleans, Indiana," by E. Randall Bayless and others.

\section{Acknowledgments}

The authors express their gratitude to members of the Orleans Rural Volunteer Fire Department for their assistance with the dye injections and to the people of Orleans for providing access to historical information and to their property.

\section{Ground-Water Levels}

A composite water-level map was used to identify subsurface drainage divides and directions of ground-water flow. A drainage divide is a boundary between adjacent drainage basins. Ground water flows from a subsurface drainage divide, usually a topographically high region, to its discharge area at a stream or spring, usually a topographically lower area.

A composite water-level map for bedrock wells was constructed from 175 well-driller's records on file with the Indiana Department of Natural Resources, Division of Water. Field measurements were made at 11 of the 175 wells to assure that the water-level records provided an accurate representation of actual ground-water levels. 


\section{Dye-Tracing Tests}

Eight dye-tracing tests were done from November 15, 1993, through March 3, 1994. Dye was injected at seven swallow holes and one stormrunoff-infiltration well. Most of the tests were done during periods following substantial rainfall when the usually dry reaches of the Lost River were inundated.

For most dye injections, water was hauled to the injection site in a 2,000 gallon tanker truck. About 200 to 500 gallons of water were poured into the swallow hole immediately before the planned dye injection. The water helped to start the flow of dye into the aquifer. After the dye was injected, an additional 200 to 500 gallons of water were used to push the dye farther into the underground-flow system.

To determine where the dye resurfaced, dye detectors were placed at known or suspected ground-waterdischarge points. Dye detectors were constructed of either undyed cotton or activated coconut charcoal encased in a fiberglass screen. The dye detectors were suspended in the main current, above bottom sediments, and were anchored down by weights. After the dye was injected, the detectors were collected and replaced at intervals of 2 to 4 days. Five dye clouds emerged at Orangeville Rise, approximately 4.5 miles southwest of Orleans. Two dye clouds emerged at Hamer Cave Spring, at Spring Mill State Park, 4.5 miles northeast of Orleans. One dye cloud emerged in seeps and springs that discharge to a tributary of the Lost River; the dye from this test was injected into a shallow storm-infiltration well and did not enter the fractures and joints of the underground limestone.

\section{Drainage Divides}

"Water flows downhill," is a statement one often hears. This truism applies when surface-water-drainage boundaries for a river basin are delineated. For the Lost River Watershed, however, it was found that the paths of ground-water flow do not coincide everywhere with the "downhill" path of surface water. Similarly, the low-lying hills that serve as a surface-water divide between Orleans and Spring Mill State Park may not be the ground-water divide for the Orangeville Rise and Twin Caves. Based on the results of dye tests and groundwater-level analysis, it appears that some of the water that discharges from Twin Caves enters the ground-water system beyond this line of hills.

\section{Flooding at Orleans}

One of the goals of this study was to improve an understanding of the hydrology of the Orleans area, including gaining a better understanding of how surface water drains towards the community, and how the surface- and subsurface-flow systems allow water to drain from the community.

Flood Creek strongly affects the hydrology of Orleans. The Flood Creek Watershed is a small watershed within the Lost River Watershed and drains approximately 8.1 square miles. During heavy rains, Flood Creek flows into a sinkhole in Orleans that is choked with the same fine-grained sediments that blanket most of the Flood Creek Watershed. These sediments are relatively impermeable silt and clay and slow the storm runoff in entering the groundwater-drainage system.

This study indicated that two engineering alternatives might decrease the magnitude of flooding in Orleans:

(1) construction of stormwater-detention structures and (2) improvements to stream drainage in the Flood Creek Watershed.

\section{Previous Investigations}

This 1993-94 study was designed to build upon work already done by other investigators. An extensive compilation of bibliographic references to previous investigations is included in the USGS Water-Resources Investigations Report 94-4195 by Bayless and others. Earlier works particularly important to this study are cited in the reference section below.

-E. Randall Bayless, Charles J. Taylor, Mark S. Hopkins, and Donald V: Arvin

\section{References}

Bassett, J.L., 1974, Hydrology and geochemistry of karst terrain, upper Lost River drainage basin, Indiana: Bloomington, Ind., Indiana University, A.M. thesis, 102 p.

Bassett, J.L. and Ruhe, R.V., 1974, Geomorphology, hydrology, and soils in karst, southern Indiana-Field Conference, April 24-25, 1974: Bloomington, Ind., Indiana University, Water Resources Research Center, 54 p.

Bayless, E.R.; Taylor, C.J.; and Hopkins, M.S., 1994, Directions of ground-water flow and locations of ground-water divides in the Lost River Watershed near Orleans, Indiana: U.S. Geological Survey WaterResources Investigations Report 94-4195, $25 \mathrm{p}$.

Malott, C.A., 1952, The swallow-holes of Lost River, Orange County, Indiana: Proceedings of the Indiana Academy of Sciences, v. 61, p. 187-231.

Murdock, S.H., and Powell, R.L., 1968, Subterranean drainage of Lost River, Orange County, Indiana: Proceedings of the Indiana Academy of Sciences, v. 77, p. 250-255.

Ruhe, R.V., 1975, Geohydrology of karst terrain, Lost River Watershed southern Indiana: Bloomington, Ind., Indiana University Water Resources Research Center, Report of Investigation No. 7, $91 \mathrm{p}$.

For more information contact any of the following:

For water information District Chief, Water Resources Division U.S. Geological Survey 5957 Lakeside Boulevard Indianapolis, IN 46278 (317) 290-3333

For map information Chief, Mapping Applications Center 567 National Center Reston, Virginia 22092 (703) 648-6002
For geologic information Assistant Chief Geologist 953 National Center Reston, Virginia 22092 (703) 648-6660

National Earthquake Information Center Denver Federal Center, Mail Stop 967 Denver, Colorado 80225 (303) 273-8494
Additional earth science information can be found by accessing the USGS "Home Page" on the World Wide Web at "http://www.usgs.gov".

For more information on all USGS reports and products (including maps, images, and computerized data), call 1-800-USA-MAPS. 